\title{
原著
}

\section{職業的な声の監用による声帯結節 患者に対するアンケート調查}

\author{
堾原 東紅 ${ }^{1)}$ 小池 董 ${ }^{2)}$
}

要 約: 声帯結節患者, 特に教師の場合, 頻回な voice therapy ができないため, 積極的な 手術治療を施行した。その結果, 術後の発声が楽になり, 自覚的に声の調子が良くない時に, できる限り声の安静に努める姿勢が生まれ，好結果が得られた。

索引用語：声帯結節, 治療, ラリンゴマイクロサージェリー, 教師, アンケート

\section{A Questionnaire Survey on Vocal Nodules Caused by Occupational Use of the Vocal Fold}

\section{Tōkō Tatehara' ${ }^{1)}$ Kaoru Koike ${ }^{2)}$}

\begin{abstract}
It is not always possible to apply frequent voice therapy to patients with vocal nodules. Therapy is particularly difficult in the case of teachers. For this reason, we treated vocal nodules surgically in many cases. After the operation, patients were able to speak easily and took care to avoid excessive vocal use when they felt their voice unnatural. In this way, excellent results were obtained.
\end{abstract}

Key words : voice nodule, therapy, laryngomicrosurgery, teacher, questionaire

\section{はじめに}

声帯結節に対するラリンゴマイクロサージェリー も，最近よく行われるようになってきたが，職業的に 声の使用が多い患者の声帯結節に対する手術は, 手術 の結果がその人のその後の人生にもかかわってくるた め，なかなか積極的になれないところがある.今回, 声帯結節に対して保存的治療および手術治療を施行し た患者に対してアンケート調査を行い, 特に教師に限 定してその結果を報告する.

\section{対象と方法}

対象は 1988 年 1 月から 1989 年 3 月までに兵庫県立 成人病センター耳鼻咽喉頭頸科を受診し, 声帯結節と 診断された患者 22 名である.アンケートの内容である が, (1)初めて耳鼻咽喉科を受診した時点の職業, (2)声 の使用状況, (3)専門教科, (4)経験年数, (5) 1 日の発声 拘束時間，6声の使用後の休息，(7)家庭での声の使用 状況，8声の異常を感じてから受診するまでの期間， 9現在の職業についてから声の異常を感じるまでの期

1) たてはら耳鼻咽候科気管食道科クリニック：テ 651-12 神戸市北区日の峰 2-3-1 神戸北町センタービル $4 \mathrm{~F}$

2) 神戸大学医学部耳鼻咽喉科：干 650 神戸市中央区楠町 7 丁目 5 番 2 号

1) Tatehara E. N. T. clinic : 2-3-1 Hinomine, Kita-ku, Köbe-shi 651-12

2) Department of Otorhinolaryngology, Kobe University School of Medicine : 7-5-2 kushunoki-cho, chuō-ku, kōbe-shi 650 原稿受理：1990 年 9 月 5 日 
間, (10)受診のきっかけとなった主訴, (11)手術後の感想, (12)手術後の改善の仕方, (13)保存的治療の種類, (14)保存 的治療のその後の経過, (15喫煙歴, などである.

\section{結果}

声帯結節患者 22 名のうち,アンケート回収数 19 例, そのうち教師は 14 名であった.表 1 は職業別細分類で ある. 書道塾の教師, カラオケ教室の教師も対象とし た. 表 2 は年齢分布である. 症例はすべて女性で, 24〜54 歳の間に分布していた。耳鼻咽候科を受診する きっかけとなった主訴は表 3 のごとくで, 最も多かっ たのが「声が嗄れている」で,「しゃべると喉が疲れる」,
表 1 職業別細分類

\begin{tabular}{l|c}
\hline 保母 (保育園・幼稚園) & 4 \\
小学校教諭 & 3 \\
中学校教諭 & 2 \\
高等学校教諭 & 1 \\
養護学校教諭 & 1 \\
書道塾教師 & 2 \\
カラオケ教室教師 & 1 \\
\hline \multicolumn{1}{c}{ 計 } & 14 \\
\hline \multicolumn{1}{c}{ 計 }
\end{tabular}

表 2 年齢分布

\begin{tabular}{c|c}
\hline $20 \sim 29$ 歳 & 3 \\
$30 \sim 39$ 歳 & 3 \\
$40 \sim 49$ 歳 & 6 \\
$50 \sim 59$ 歳 & 2 \\
\hline 計 & 14 \\
\hline
\end{tabular}

「声が続かない」の順で多い, 毎日の生活の中で非常な 苦痛を感じていると訴えている. 表 4 は 1 日の声の使 用の拘束時間である. 最低でも 4 時間, 養護教諭など は 13 時間という症例もあった.表 5 は現在の職業につ いてから声の異常を感じるまでの期間を示した. 就職 してすぐ嗄声が出現した症例もあり,また 30 年以上経 ってから症状が出現した症例もあった. 表 6 は声の休 息の状況を示す．「全く休息できない」が 6 例,「少し 休息できる」が 7 例, 「十分休息できる」と答えたのが 1 例であった。治療に関しては, 表 7 のごとく症例数 14 例のうち, 全身麻酔下ラリンゴマイクロサージェリ 一を施行したのが 9 例, 保存的治療を施行したのが,

\begin{tabular}{l|r}
\multicolumn{1}{c}{ 表 3 主 } & \multicolumn{1}{c}{ 訴 } \\
\hline 声がかれている & 12 \\
しゃべると䐅が疲れる & 9 \\
声が続かない & 8 \\
喉がひりひりする & 7 \\
喉が痛い & 6 \\
喉が乾く & 4 \\
疢がきれない & 4 \\
声が低くなった & 2 \\
喉に何かつまっている & 1 \\
\hline
\end{tabular}

表 4 1 日の発声を拘 束される時間

\begin{tabular}{cc}
\multicolumn{2}{c}{ 束される時間 } \\
\hline 4 時間 & 1 \\
5 時間 & 3 \\
6 時間 & 3 \\
7 時間 & 2 \\
8 時間 & 2 \\
9 時間 & 2 \\
13 時間 & 1 \\
\hline 計 & 14 \\
\hline
\end{tabular}

表 5 現在の職業についてから声 の異常を感じるまでの期間

\begin{tabular}{c|c} 
表 5 & \multicolumn{2}{c}{$\begin{array}{c}\text { 現在の職業についてから声 } \\
\text { の異常を感じるまでの期間 }\end{array}$} \\
\hline 1 年 & 1 \\
3 年 & 2 \\
4 年 & 3 \\
6 年 & 2 \\
9 年 & 1 \\
10 年 & 2 \\
11 年 & 1 \\
21 年 & 1 \\
30 年 & 1 \\
\hline 計 & 14 \\
\hline
\end{tabular}

\begin{tabular}{lr} 
表 6 & 声の休息の状況 \\
\hline 全く休息できない & 6 \\
少し休息できる & 7 \\
充分休息できる & 1 \\
\hline \multicolumn{1}{c}{ 計 } & 14 \\
\hline
\end{tabular}

表 7 治 療

\begin{tabular}{lr}
\hline $\begin{array}{l}\text { ラリンゴマイクロサージェリー } \\
\text { 保存的治療 }\end{array}$ & 9 \\
未治療 & 3 \\
& \multicolumn{1}{c}{ 計 } \\
\hline
\end{tabular}

表 8 保存的治療および未治療の結果

\begin{tabular}{ll|ll}
\cline { 1 - 1 } 外来治療 & 2 & 改善された & 2 \\
\cline { 1 - 2 } 声の安静のみ & 1 & \multirow{2}{*}{ 改善されない } & 3 \\
\cline { 1 - 2 } 未治療 & 2 & & \\
\hline
\end{tabular}




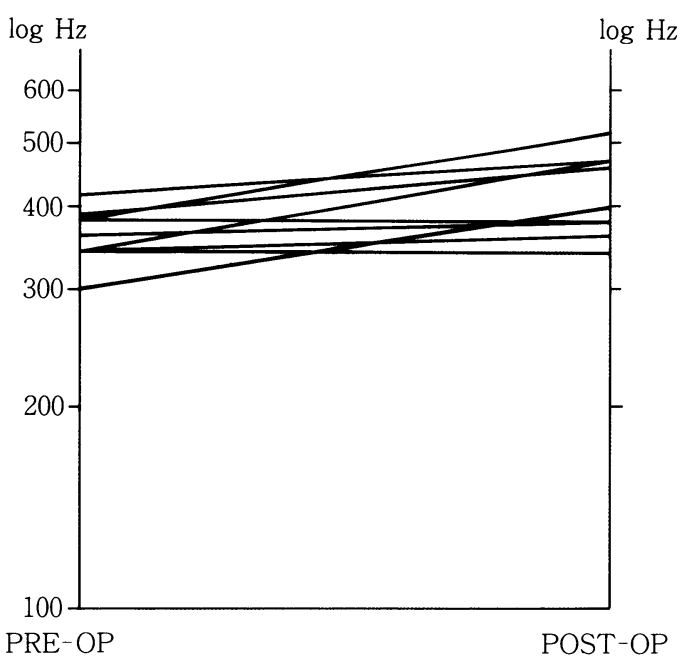

図 1 術前後の最高音域の動向

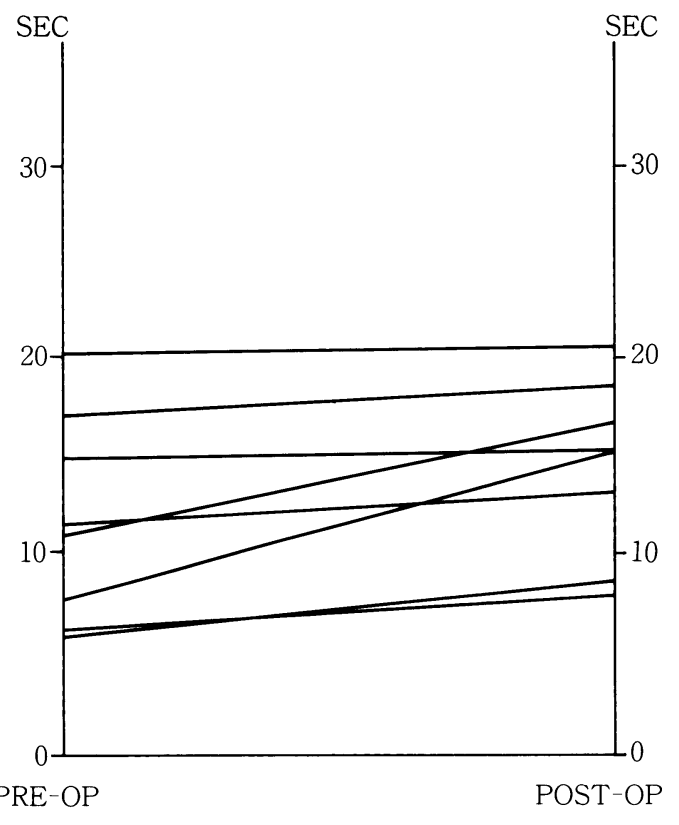

図 2 術前後における最大発声持続時間の動向

\begin{tabular}{|c|c|c|}
\hline \multirow{3}{*}{\multicolumn{2}{|c|}{$\begin{array}{l}\text { 非常によくなった } \\
\text { 相当よくなった } \\
\text { 少しよくなった }\end{array}$}} & 1 \\
\hline & & 6 \\
\hline & & 2 \\
\hline 不 & 変 & 0 \\
\hline 悪 & 化 & 0 \\
\hline & 計 & 9 \\
\hline
\end{tabular}

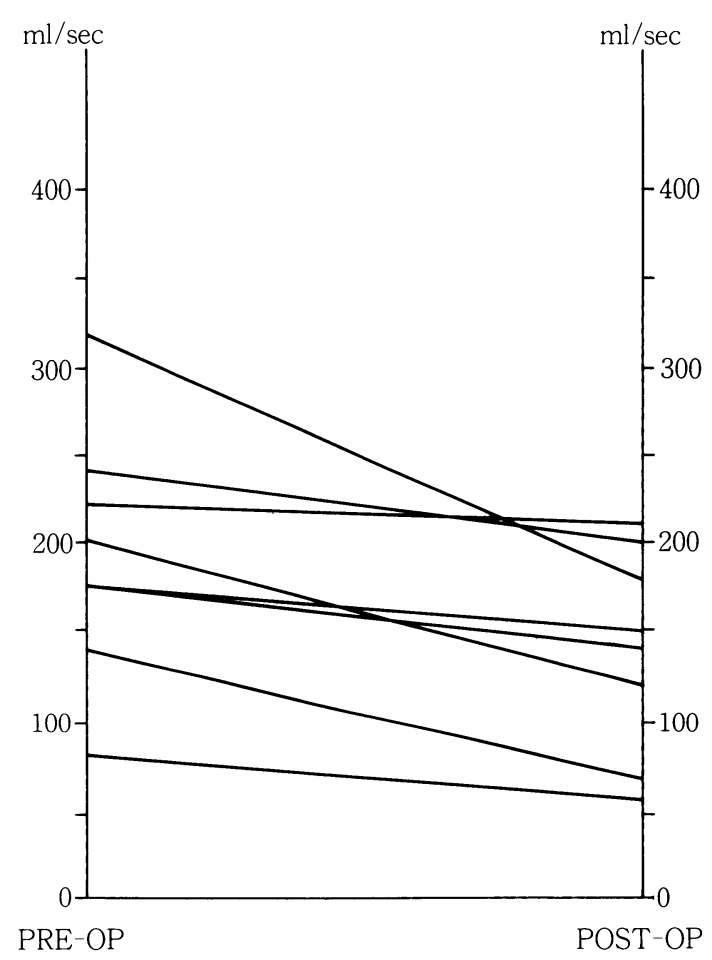

図 3 術前後の最小発声時平均呼気流率の動向

3 例, 未治療 2 例であった。保存的治療および未治療 の結果は, 表 8 のごとくである. 保存的治療施行の 5 例のうち, 2 例は外来通院にて喉のネビュライザーに よる吸入および職場でのできる限りの声の安静を行 い, 改善されたと答えている. 外来通院せず, 声の安 静のみにつとめた 1 例と, 未治療例 2 例は改善されな いと答えている. 表 9 は, 全身麻酔下ラリンゴマイク ロサージェリーを施行した 9 例の術後の状況である が，「非常に良くなった」と答えた症例は 1 例のみであ つた.「相当良くなった」と答えたのは 6 例, 「少し良 くなった」と答えたのが 2 例で，「不変・悪化した」と 答えた症例はなかった. 図 1 は声域の最も高音部の術 前および術後 1 力月の比較のグラフであるが, 著明な 改善は認められなかった。図 2 は術前および術後 1 力 月の最大発声持続時間の比較のグラフである. 術前が それほど短い症例が少なく, 改善度も著しく良いとい う結果ではなかった. 図 3 は最小発声時の平均呼気流 率の術前および術後 1 力月の比較である.

\section{考察}

声帯結節の治療は手術治療と保存的治療に大別され る. 保存的治療は, 一般には通院による薬物治療や吸 入治療が主流で，その効果はあまり期待できない。し 
かし, 最近は発声指導による治療も行われるようにな り, 諸家により良好な結果が報告されている ${ }^{1 \sim 3)}$.一方, 手術治療は, 平野, 斎藤, 一色ら ${ }^{4 \sim 6)}$ の系統的研究によ り, 音声外科が臨床的にも基礎的にも確立するに従い 良好な成績が得られるようになってきた。今回も全例, 全身麻酔下ラリンゴマイクロサージェリーを施行し た. 表 1 で教師の細分類を示したが, 症例が少ないた め, 職業の種類ごとによる特色を評価することはでき なかった. 表 3 の主訴は, さまざまな訴えがみられた。 表 4, 表 6 に示すように教師の声の酷使は休めないと か, 声を使用しなければならない時間の長さからみて も非常なものであると考えられる。また広い教室での マイクなしの発声, 保育園や小学校など低学年ならば 児童の騒音下での無理な発声なども声帯の酷使に関与 しているものと考えられる. 図 1 , 図 2 に示すように, 声帯結節に対するラリンゴマイクロサージェリーの結 果をみると, 声域の拡大, 最大発声持続時間の延長な どはわずかであり, 最小発声時の平均呼気流率の減少 が認められる程度である. 職業歌手のような, 短時間 の声の酷使と異なり, 教師のように時間経過の長い声 の酷使は, 声帯粘膜上皮の炎症あるいは血管拡張によ る声帯の微妙な物性の変化やルブリケーションの低下 をきたすと考えられ，そのため手術により結節が消失 していても, 音声が非常に良くなったと答える症例が 少ないのではないかと考えられる.したがって, 術後, 同じ職場環境で声をだしていかざるを得ない状況で は, 周囲の騒音環境の改善, マイクの使用などにより 再発の防止に努めて行かなければならない。

ラリンゴマイクロサージェリーにより, 結節が消失 し, 声門閉鎖が完全になっても, やはり嗄声成分は残 り, 術後の発声指導が重要であることはいうまでもな い. 最近は, 声帯結節に対して, 発声指導のみで保存 的に効果をあげている施設があり，このような方法で 音声が改善すれば, それが最善であることはいうまで もないが，教師の中には，通院のための， 2 週間に 1
度の休㖊も取れない状況の人が多く, 今回のアンケー 卜調査により，そのような状況の患者に対しては，手 術を施行し, 術後の発声が楽になった上で発声指導を 行った方がより効果が上がり, また, 自覚的に声の調 子が良くない時に, できる限り声の安静に努める姿勢 が生まれ好結果を与えたと考えられた。

\section{ま と め}

職業的に声を濫用する声帯結節患者, 特に教師 14 例 に対するアンケート調查を施行した結果, 教師の声帯 結節は保存的治療で改善しない例が多く, 手術治療で は全症例で改善がみられた。

本論文の要旨は, 第 34 回日本音声言語医学会, 第 105 回日耳鼻 兵庫県地方部会 (耳鼻咽候科, 頭頸部外科学会) にて発表した。

\section{文献}

1）渡辺陽子，他：声帯結節に対する voice therapy. 耳鼻, $29 ： 949-952,1983$.

2）山口宏也, 他 : 声帯結節症例に対する音声訓練の 検討. 日耳鼻，89：1423-1424，1986.

3）四倉淑枝：声帯結節に対する音声治療の研究.日 耳鼻, 90：1387-1401，1987.

4）平野 実：音声外科の基礎と臨床. 耳鼻, $21: 239$ $-440,1975$.

5）斎藤成司：音声外科一発声機構の基礎的研究およ び喉頭内腔への臨床的アプローチー. 耳鼻, 23 (補 冊 1 号)：171-374， 1977.

6）一色信彦：㑨頭機能外科（とくに経皮的アプロー チ). 京都大学医学部耳鼻咽喉科同空会編, 1977.

別刷請求先: $\mathbf{T} 651-12$ 兵庫県神戸市北区山田町下谷上字猪 ころび $4-12$

苶原東紅 